DOI: $10.17516 / 1997-1370-0540$

УДК 340.12:165.723

\title{
The Principle of Relativity in the Post-Classical Theory of Law
}

\author{
Il'ia L. Chestnov ${ }^{a}$ and Ekaterina G. Samokhinab* \\ ${ }^{a}$ St. Petersburg Institute (branch) of University of the General Prosecutor's Office \\ St. Petersburg, Russian Federation \\ ${ }^{b}$ National Research University Higher School of Economics \\ St. Petersburg, Russian Federation
}

Received 08.10.2019, received in revised form 30.12.2019, accepted 10.01.2020

\begin{abstract}
The article discusses up-to-date methodological issues of relativity in legal science. Relativity considered as the relativity of knowledge about an object characterises modern Post-Classical philosophy and science. Radical relativity as a pluralism in the sphere of values causes the well-founded concern of many scientists. The authors of the article propose their own vision of the content of relativity as a methodological principle of the Post-Classical legal science. The Post-Classical methodology used by the authors suggests criticising classical jurisprudence and dialogism (the interdependence of opposing points) as a positive programme. Relativity in law, according to the authors, is the pre-dependence of law by the social and cultural context, the interdependence of law and other social phenomena. Law does not exist "in its pure form", but always appears as a side or aspect of the psyche, culture, economy and politics. Such an approach is not identical to arbitrariness, since law, in conjunction with other social phenomena, is intended to ensure the integrity of society. The proposed approach provides a deeper picture of a multidimensional legal reality and represents a version of a new Post-Classical methodology that is adequate to a contemporary society.
\end{abstract}

Keywords: relativity in law, methodology of legal science, Post-Classical methodology of law, autonomy of law.

Research area: law.

Citation: Chestnov, I.L., Samokhina, E.G. (2020). The principle of relativity in the post-classical theory of law. J. Sib. Fed. Univ. Humanit. Soc. Sci., 13(1), 42-49. DOI: 10.17516/1997-1370-0540

\footnotetext{
(C) Siberian Federal University. All rights reserved

* Corresponding author E-mail address: ilchestnov@yandex.ru, esamokhina@hse.ru ORCID: 0000-0003-2083-5876 (Chestnov); 0000-0002-8030-8034 (Samokhina)
} 


\section{Introduction}

Being one of the principles of Post-Classical philosophy and epistemology, relativity can be defined as uncertainty of knowledge about intersubjective communications, which are embedded in trans-cultural contexts. After the Classical Worldview (or "mechanistic", Cartesian science etc.) was replaced by the Post-Classical science, a new epistemological idea was put forward that the Knowledge about any object always remains incomplete, limited, stipulated by dominant values, ideology, public opinion, scientific traditions, etc.

Sociological epistemology from the beginning of $1970 \mathrm{~s}$ of the $20^{\text {th }}$ century focuses on the influence that intersubjective relations, social and cultural context exert on scientific knowledge (see for example, Barnes, 1974, 1977, 1981; Barnes \& Bloor, 1982). An important role in molding the conception of relativity belongs to the principle of complementarity discovered by Niels Bohr, according to which objects have certain pairs of complementary properties which cannot all be observed or measured simultaneously (Bohr, 1995). Complementarity gained the importance of the generally valid methodological basis of scientific research. In the history of science, the meaning of this principle was unfold as contextuality of any scientific knowledge - its dependence on observer's world outlook, critics of the dominant Worldview, and, therefore, incommensurability of different scientific paradigms. That is why, for example, scientific proof or facts are always considered as "having a deep theoretical sense"; because their meaning depends on the way they are characterised from the point of view of a certain theory; taken abstractly, without reference to a theory, they do not convey any relevant information.

In this talk about relativism, Goedel's theorems cannot be neglected; these theorems deny existence of any formalised, uncontroversial and complete (closed) systems. Goedel's first incompleteness theorem states that in case a system (a set) is consistent, it shall also be incomplete (unclosed); but if the system is complete, it is inconsistent.
The "linguistic" turn in socio-humanitarian knowledge brought about the idea of relationship between social reality and the representations the subjects have about it. "It is not important whether or not the interpretation is correct - if men define situations as real, they are real in their consequences", as it is asserted in Thomas's theorem (Thomas $\&$ Thomas, 1928: 571-572). This idea is supported by the proponents of social phenomenology. That is why the principle of relativity in scientific knowledge turns into ontological relativity in social existence: social reality does not exist outside of its symbolic (linguistic) expression.

Thereby, the principle of relativity overcomes the naïvely realistic concept of knowledge and of the reality: knowledge cannot mirror the world as it is, like Richard Rorty's "mirror of nature" (Rorty, 1979), since a comparison between the concept of reality and the reality itself is never possible. What is possible - it is only to capture the concept of reality (see Rockmore, 2005). At the same time, the idea of relativity brought to socio-humanitarian sciences causes the great concern of philosophers, sociologists, and lawyers in regard to radical pluralism, blurring the foundations of society (Lectorsky, 2015: 5). This article poses the question: is the approach based on the principle of relativity so harmful and damaging for social sciences and for jurisprudence, in particular?

\section{Theoretical Framework}

All these characteristics mentioned above remain relevant to juridical knowledge that preserves only a relative autonomy in the sphere of socio-humanitarian knowledge. Juridical knowledge is influenced by social and cultural context, in which dominant models of thinking about law influence formation of this juridical knowledge. Legal science is a kind of sociological theory; the content of this science is determined by its connection with social philosophy and other social sciences. However, if legal knowledge is relative (socially determined), Hegel's thesis that law emerges only as a moment, as a part of the society, is sustained also from the Post-Classical perspective. 


\section{Statement of the Problem}

In connection with all that has been mentioned above, we can articulate the following ontological principle of relativity in legal sphere: law is a social phenomenon shaped by its interactions with other social phenomena and with society as a whole. Without this interaction, law does not exist as such.

Here one may suggest a thesis which appears to be provoking: there are no "pure" legal phenomena, and a "pure legal system", similar to the one described by Hans Kelsen, could never exist. Like all social institutions, law (though having no unitary referent in the social reality) is always multifaceted, multivariable and exists in social reality due to social interactions, which are shaped by social representations of actors. These interactions usually include mental phenomena, culture, language, sometimes - economical, political and other relations. For instance, it is only by means of analytical procedure of discerning abstract moments in the social phenomenon that we could pick up legal aspects in a sale contract, in a contract of carriage or in voting at a polling station, differentiating them from political, economical and other facets. Moreover, there are no legal phenomena (statutes, court decisions, legal relations) that are not at the same time mental economical, political - or in a broader sense socio-cultural phenomena. One can find support to this idea in the works of the outstanding Polish legal philosopher Leon Petrazycki (Petrazycki, 2011). This varying aspect of law intersects with the neutral, from the first sight, phenomena like gender, race, religion, political views.

\section{Methods}

The most appropriate methodology for the study of the law in contemporary world seems to be a Post-Classical research programme. It assumes criticism of classical jurisprudence and postulates the impossibility of creating law as a closed, self-sufficient system. This quality of the Post-Classical research programme justifies the inevitable relativity as a content of the Post-Classical methodology. In turn, from a methodological perspective, relativity appears as a rejection of fundamentalism, essentialism and naturalism in favour of contextuality, sociocultural conditionality of law, and its dialogical nature understood as interdependence with other social phenomena and processes. Specific methods that help to clarify the dialogical nature of law are methods of narrative linguistics, psycholinguistics, expressing a linguistic turn, and methods of critical discourse analysis, ethnomethodology, social phenomenology, method of "rich description" taken from sociocultural anthropology, etc. used in the Post-Classical legal science.

\section{Discussion}

Such intersection has been thoroughly investigated by the American legal realists in the 20-30s of the 20 $0^{\text {th }}$ century (among others by Karl Llewellyn, Oliver Holmes Jr., Jerome Frank). Their studies demonstrated that not only race, but also gender of the accused person, and other factors can influence the court decision.

In jurisprudence, the principle of complementarity has never been applied in a direct way. However, it is possible to find the examples of its "indirect" application; for example, this principle was used by one of the contemporary adepts of the Critical Legal Studies in the USA, Professor Pierre Schlag (Schlag, 1991a, 1991b). Schlag raises the problem of a legal subject and a view of law taken "from the inside" (from the judge's point of view). Such a view, in his opinion, is inevitably unilateral, and leads to a radical simplification of the law (Schlag, 1991b: 1115). From such unilateral perspective flows a belief that there is the only true ontology of law which is independent from all subjects (except judges). This justifies the inevitability of relativity in a form of multiple different approaches to law.

To illustrate this idea, one can mention the example of Yakov Gilinsky, one of those Russian lawyers who used the principle of complementarity in working out the methodology of criminological research. His methodology sums up the principle of relativity of knowledge with the assertion of extraordinary complexity of even most "ordinary" objects. In Gilinsky's opinion, the principle of complementarity in Bohr's sense can be reformulated as "sontgagia 
sunt complementa" (complementary opposites): only contradictory, mutually exclusive concepts taken together can adequately describe the examined object. What this approach implies is not overcoming the controversial nature of the object, but complementarity of the controversies inside this object (Gilinsky, 2009: 25-26). "Knowledge about any object of the reality is relative, incomplete and limited. One can never achieve complete and final knowledge about the object of the research. This is, first of all, due to the fact that all objects of the reality exist in a state of constant transformation. ... In addition, the possibilities of human knowledge are always limited by the means available at any given time. ... Everything that was said above is not a call to abandon the knowledge of the reality (including crime), but a warning against absolutisation of the obtained knowledge" (Gilinsky, 2009: 25).

Contrary to Kelsen, it is impossible to justify a "pure system of law" which would be an uncontroversial, complete, closed entity, liberated from the "dust" of the politic, economic and social reality. First, because this justification would come into conflict with the second law of thermodynamics: there are no closed systems in the real world insomuch as entropy in such systems would constantly increase, and thereby these systems would be inevitably led to their self-destruction. That is why the social systems, which exist in the real world, are open, and are able to share substance and energy with their environment.

Secondly, Goedel's incompleteness theorems, as mentioned above, demonstrate that consistent, complete and closed systems could never actually exist. To justify a system by means of formal logic, it is necessary to point out at the starting axiom (like Kelsen's Basic Norm), from the position of which people could argue about legal validity of constitution, statutes, and so on. Nevertheless, if the starting axiom appears under the guise of Kelsen's Basic Norm (the content of which is absolutely empty), or of Hart's rule of recognition (that has no constant definition), how could we be sure that a constitution (for example, the Constitution of the USSR of 1936) is valid in logical and juridical sense?
Legal norm cannot be justified even with the help of the concept of natural law. As an example, one can take the theory of Professor Robert Alexy (Alexy, 2011). Prof. Alexy argues that there is a necessary connection between law and morality, and believes that axiomatic basis of the legal system cannot be justified by any other legal norm, but it can be justified on the base of certain moral principles (Alexy, 2011, 142).

However, we cannot agree with Professor Alexy and other proponents of natural law concept, if we reassess their ideas in the light of the principle of relativism. The reason of our disagreement lies in the fact that such basic moral principles as freedom or justice have different interpretations in different cultures in different historical eras. Anna Wierzbicka demonstrates that freedom for a Western European means a certain benefit that provides the individual with opportunity to act, the extent of this opportunity being limited by freedom of other members of the community. (One may legitimately mention "freedom" here because law is usually defined as a measure of freedom). In Wierzbicka's description, for the Slavonic people (the Russians and the Poles) freedom is rather connected with familiarity, permissiveness, nihilism towards the rules, and so on. All the same, for the Russians and the Poles this freedom brings a benefit in the same manner as for Western Europeans. Nevertheless, for the Japanese people freedom is not a value, because culturally it is associated with opposition of an individual to the society, to the collectivity (Wierzbicka, 1991: 333-385).

In this regard, we could agree with the position of Alasdair MacIntyre, who suggests that there are no definite answers to the questions connected with moral or political values. He argued about impossibility of rational choice between different moral values; for him concepts of justice, morals, law should be regarded as necessarily dependent on a particular cultural tradition. Thus, from the point of view of MacIntyre, there is no neutral, pre-theoretic basis, which allows settling disagreement between different conflicting opinions (MacIntyre, 1990: 172-173). 
In social science this problem is discussed under the title of "essential contestability" of such notions as justice, freedom, democracy because of their polysemantic, complex and axiological nature. Any definition or interpretation of these notions, if we accept the theoretical standpoint of Walter Bryce Gallie, may not claim for priority before other definitions or interpretations; thus, any point of view could be theoretically justified and contested. Moreover, it is impossible to endorse adequacy of such definitions or interpretations with help of any empirical criteria. The dispute between different claims to adequacy is therefore irresolvable (Gallie, 1955).

In this regard, Ronald Dworkin suggests that legal principles and court decisions have no direct connection between each other, and uncertainty of the basic constitutional standards always leads to discrepancies when such principles are applied by rational human beings (Dworkin, 1978). That is why the word "right" has different meanings in different contexts. The eminent anthropologist D'Andrade suggests that there are no logic connections between constitutive norms (or cultural norms that could be treated as legal principles) and regulative norms: a variety of constitutive rules could be connected with absolutely different norms of different subcultures (D'Andrade, 1984: 91-93).

The theory of autopoiesis developed by Niklas Luhmann, and applied to the legal studies by Professor Werner Krawietz and Professor Mark Van Hoecke, demonstrates self-organisation and proves completeness of legal system, but also contains several controversial points which make it non-resistant to critics based on relativist methodology. Prof. Krawietz argues that system of law is able to qualify its internal operations as law/non-law, valid/invalid, legal/ illegal.... The sphere of law is differentiated through binary codes; if something is permitted or prohibited in such a system, this something will at the same time be jurally permitted or prohibited. Such a binary code excludes other types of discourse. In this regard, the purpose of a binary code is production (which always presupposes re-production) of legal decisions within the framework of a self-referential le- gal system of directives and norms, which, by means of constant interlinking of communications, gives rise to new directives (Krawietz, 2000: 34-46). However, such approach does not explain who and how defines the law/nonlaw code, which allows differentiating between law and non-law.

Almost all lawyers, trying to explain definition of this code, consider this problem as connected not with jurisprudence but with politics of law. In our opinion, such simplified approach would impoverish legal theory and philosophy, and this problem necessitates further reflections about differentiation of law. So far as legal system develops and changes itself, it is subject to "inflation of legislation". Lawyers shall study these processes. Each system of law is changing under influence of interpretation. Such interpretation is given in court decisions, especially when judges face hard, complicated cases, adjudicating in which they have to recourse to moral principles. This fact shows that operative completeness and consistency is nothing but a methodological condition for analysing law.

This idea was advocated by Professor Mark Van Hoecke, who states that legal systems contrasting, for example, to mathematical systems, are not independent from the society to which they belong, and which in its turn is organised through law. Each legal system represents a part of a more general social system. Legal system appears as a way of organisation of social, economical, moral, and other kinds of behaviour. That is why legal systems must be related with the society. At the same time, legal systems are embedded in the society and thus are strictly determined by it, even if they still are conceived as relatively autonomous to other blocks of sociality. In the weak sense "autonomy" means only that legal norm or legal system can be identified as something different from morality, religion or another system of rules, and that the matter is not just about mirroring a set of extra-legal rules. However, according to Professor Van Hoecke, there exists a methodological autonomy, which embraces three aspects: a) linguistic autonomy (development of technical language of lawyers); b) autonomy 
of style (stylistic of statutes, legal decisions, contracts, etc.); c) autonomy of argumentation (Van Hoecke M., 2002).

In this perspective Van Hoecke agrees with Eugenio Bulygin and Carlos Alchourron who claim that "the so-called postulate of hermetic plenitude (or of necessary completeness) of the law - which is a juristic version of the same thesis - is not justified in its claim that every legal system is complete. It is important to emphasise the difference between the postulate of completeness, according to which all legal systems are in fact complete, and the requirement that they should be complete. The former is, at best, a mere illusion which nonetheless plays a definite ideological part in legal thought, while the latter is a purely rational ideal independent of any political attitude" (Alchourrón, Bulygin, 1971).

The fact that law cannot be considered as an axiomatic and deductive system was discussed by the famous Hungarian theorist of law C. Varga. In his opinion, this is due to the fact that law "has no fundamental concepts that have a self-evident meaning; no principles of interpretation are defined exhaustively or are not constructed from the system; moreover, legal concepts are not necessarily deducible from the system itself. If so, then law is not suitable for axiomatisation due to the very nature of its concepts, in view of the fact that the very idea of deduction is alien to them (Varga, 2009). Relativity of law, first of all, is connected with its versatility, polymodality.

However, it does not mean that relativity of law is associated with arbitrariness and anarchy. Relativity of law means its conditionality. From the point of view of legal sociology, law (like all the other social institutions) solves certain social problems: first of all, it guaranties normal functioning of society. This effect can be reached either through legal regulation of social relations, or by means of distribution of economical wealth, or by means of political decision-making in the public sphere. This aspect allows revealing the minimum of universal features of law. We say "minimum" because here one can see only abstract law, which gets its particular contents in different historical eras in different cultures. Relativity of law leads the researcher to inability to formulate universal criteria for establishing absolutely forbidden actions.

Therefore, Professor Yakov Gilinsky points that "there is no such an object which could be called "criminality" in society, and which has such essential characteristics proving this qualification. Such concepts as crime and criminality are relative, uncertain and conventional: they never reflect the social reality as such and always represent some kind of social agreement". We consider murder or stealing as crimes, but we do not assert a crime where someone kills an enemy during the war, if someone executes death sentence, etc. (Gilinsky, 2009: 37).

We could hardly ignore these ideas, but it is true that no society could exist without norms of criminal law, for example. Every society creates some positive social norms that protect this society from wrongdoers and help to provide its safety. The main problem of legal theory is to bring these norms to light. Today it is impossible to formulate universal criteria for their clarification, but it does not mean that there are no such criteria at all. Discovering such norms presupposes a preliminary socio-legal analysis of the specific society that will set positive social norms that guarantee its integrity.

\section{Conclusion}

Thus, the principle of relativity in law means the necessity to abandon universalism and to examine deeper historical and socio-cultural contextualism of development of law. Abandoning universalism means rejection of any claims on the part of legal science to find definitive answers to the question about nature of law. There is no universal law (and no eternal essence of law) given for all times and places. To grasp the specificity of law, one must acknowledge contextualism of law, i.e., the fact that history, culture, civilisation of a society prefigures perception of law by the elite and by the population of this society. From this standpoint, one can also explain transition of legal institutions in society. What can allow us to demarcate different legal rules and institutions as law, and differentiate them from the rest of 
sociality? The answer is to be sought in the fact that these rules and institutions have developed in a certain society, that they provide self-preservation and survival of this society.

\section{References}

Alchourrón, C.E., Bulygin, E. (1971). Normative Systems. New York. P. 6. Oxford.

Alexy, R. (2002). The Argument from Injustice, trans. S.L. Paulson and Bonnie Litschewski Paulson.

Barnes, B. (1974). Scientific Knowledge and Sociological Theory, Boston: Routledge and K. Paul.

Barnes, B. (1977). Interests and the growth of knowledge, Boston: Routledge and K. Paul.

Barnes, B. (1981). On the Conventional Character of Knowledge and Cognition. In Philosophy of the Social Sciences, 11(3), 303-333.

Barnes, B., Bloor, D. (1982). Relativism, Rationalism and the Sociology of Knowledge, Hollis, M.; Lukes, S. (ed.). In Rationality and Relativism, Cambridge (Mass.), MIT Press, 21-47.

Barnes, B. (1982). On the Extensions of Concepts and the Growth of Knowledge. In Sociological Review, 30(1), 23-45.

Bohr, N. (1995). Causality and Complementarity: supplementary papers edited by Jan Faye and Henry J. Folse. The Philosophical Writings of Niels Bohr, Volume IV. Ox Bow Press.

D’Andrade, R.G. (1984). Cultural Meaning Systems. Shweder R.A., LeVine R.A. (eds.) Cultural Theory. Essays on Mind, Self and Emotion. Cambridge, London, N.Y., New Rochelle, Melbourne, Sydney. Cambridge University Press, p. 88-122.

Dworkin, R. (1978). Taking Rights Seriously Harvard.

Gallie, W.B. (1955) Essentially Contested Concept. In Proceedings of the Aristotelian Society, 56, 167-198.

MacIntyre, A. (1990). Three Rival Versions of Moral Enquiry: Encyclopaedia, Genealogy, and Tradition. University of Notre Dame Press, Notre Dame.

Gilinsky, Y. (2009). Kriminologiia: teotiia, istoriia, empiricheskaia basa, sotsial'nyi control [Criminology: Theory, history, empirical basement, social control]. Saint-Petersburg.

Krawietz, W. (2000). The Concept of Law Revised - Directives and Norms in the Perspectives of a New Legal Realism. In Ratio Juris, 14, 34-46.

Lectorsky, V.A. (2015). Reliativism I pluralism v sovremennoi kulture [Relativity and pluralism in modern culture]. In Reliativism kak bolezn' sovremennoi filosofii [Relativity as a sickness of modern philosophy], Moscow.

Petrazycki, L. (2011). Law and Morality. Transl. by Hugh W. Babb. With an Introd. by Nicholas S. Timasheff, ed. by A.J. Trevino. New York.

Rockmore, T. (2005). On Constructivist Epistemology. New York.

Rorty, R. (1979). Philosophy and the Mirror of Nature. Princeton.

Schlag, P. (1991a). The Problem of the Subject. In Texas Law Review, 69.

Schlag, P. (1991b). Normativity and the Politics of Form. In University of Pennsylvania Law Review, 139.

Thomas, W.I., Thomas, D.S. (1928). The child in America: Behavior problems and programs. New York, 1928.

Van Hoecke, M. (2002). Law as Communication. Oxford: Hart Publishing.

Varga, Cs. (2005). The Nature of Law and Legal Thinking [La notion de justice aujourd'hui]. Petre Mares, Jean-Pierre Clero eds. Târgovişte: Valahia University Press. P. 112-124.

Varga Cs. (2009). The Quest for Formalism in Law. In Acta Juridica Hungarica, 50(1), 1-30.

Wierzbicka, A. (1991). Japanese key words and core cultural values. In Language in Society, 20, 333 385 . 


\title{
Принцип релятивизма в постклассической теории права
}

\author{
И.Л. Честнова ${ }^{\text {, Е.Г. Самохинаб }}$ \\ ${ }^{a}$ Санкт-Петербургский институт (филиал) \\ Университета Генеральной Прокуратуры \\ Российская Федераичи, Санкт-Петербург \\ ${ }^{6}$ Национальный исследовательский университет \\ «Выстия шккола экономики» \\ Российская Федерация, Санкт-Петербург
}

\begin{abstract}
Аннотация. В статье обсуждаются дискуссионные методологические вопросы релятивизма в юридической науке. Релятивизм как относительность знания об объекте характеризует современную постклассическую философию и науку. Радикальный релятивизм как ценностный плюрализм вызывает обоснованную обеспокоенность многих ученых. Авторы статьи предлагают свое видение содержания релятивизма как методологического принципа постклассической юридической науки. Постклассическая методология, используемая авторами, предполагает критику классической юриспруденции и диалогизм (взаимообусловленность противоположных моментов) как позитивную программу. Релятивизм в праве, по мнению авторов, - это обусловленность права социокультурным контекстом, взаимозависимость права и других социальных явлений. Право не существует «в чистом виде», а всегда выступает как сторона или аспект психики, культуры, экономики, политики. Такой подход не тождествен произволу, так как право во взаимосвязи с другими социальными явлениями призвано обеспечивать целостность социума. Предлагаемый подход дает более глубокую картину многомерной правовой реальности и представляет собой вариант новой постклассической методологии, адекватной постсовременному обществу.
\end{abstract}

Ключевые слова: релятивизм в праве, методология юридической науки, постклассическая методология права, автономность права.

Научная специальность: 12.00.00 - юридические науки. 